\title{
The Pragmatics of Prophecy in John Knox's The First Blast of the Trumpet Against the Monstrous Regiment of Women
}

\author{
CHAD SCHROCK \\ The Pennsylvania State University
}

\begin{abstract}
Bien que le The First Blast of the Trumpet Against the Monstrous Regiment of Women de John Knox ait été écrit pour nuire au règne catholique de Mary Tudor, cet ouvrage a plutôt provoquél' hostilité de son successeur au trône, Élisabeth. Si l' image prophétique que projette Knox volontairement a survécu à ce manque de prévoyance, c'est uniquement en raison de ses pratiques en matière prophétiques et des modèles vétérotestamentaires qu'il a choisis d'imiter. Dans The First Blast, sa prophétie est principalement de nature interprétative plutôt que prédictive, alors que les prophètes d'après lesquels il a façonné son image ont surtout vécu durant le déclin d'Israël et que leurs durs avertissements étaient voués à l'échec. D'aprèsl'image que Knox s'est construite, le prophète divinement inspiré peut dans tous les cas ne pas se soucier des conséquences de cette sorte.
\end{abstract}

$\mathrm{J}$

ohn Knox's The First Blast of the Trumpet Against the Monstrous Regiment of Women was disastrously, embarrassingly, comically ill-timed, notorious as one of the least contextually appropriate publications in history. When Knox wrote The First Blast in the city of Dieppe during the winter of $1557-58$, Mary Tudor was Queen of England and an implacable foe to Protestants like himself; she killed them and, worse, disempowered them. If she were to remain on the throne, all that John Knox hoped for England came under tremendous threat; he aimed The First Blast directly at her. But in November 1558 Elizabeth succeeded Mary as Queen of England, bringing potential Protestant sympathies. In order to realize that potential, the Marian exiles ought to have treated the mercurial Elizabeth gingerly, and approached her with a tentative alliance. If they had affirmed Elizabeth's already precarious authority, she would have been able to control England more securely; and the exiled Protestants could have won a grateful monarch — as sympathetic to their religious aims as they were to her political ones. Unfortunately, Elizabeth read The First Blast's absolute and comprehensive denunciation of female secular authority, and the best chance for a radical Protestant England in something like the image of Knox or Calvin seemed, to the Reformers, spoilt before it ever began. All over Europe, Protestants winced at The First Blast and covered their ears. A distinguished roster quickly recorded their

Renaissance and Reformation / Renaissance et Réforme 30.2, Spring/printemps 2006 
84 CHAD SCHROCK

distaste, among them Heinrich Bullinger, John Calvin, Théodore de Bèze, Matthew Parker, John Foxe, and John Aylmer, ${ }^{1}$ who wrote an official repudiation of the tract. Calvin, attempting to distance himself from the renegade Knox and reinstate Genevan Protestantism in Elizabeth's favour, wrote an irked letter to Elizabeth's Secretary of State Sir William Cecil, calling The First Blast "evil" and complaining that it had endangered the entire Marian exilic community: "By reason of the thoughtless arrogance of one individual, the wretched crowd of exiles would have been driven away, not only from this city but even from almost the whole world." Knox himself admitted in a 1559 letter that "My First Blast hath blown from me all my friends in England" (4:353). In short, The First Blast was an ill-judged, unnecessary antagonism toward women in power as well as a dangerously divisive force within emerging Protestantism itself, something even Knox tacitly acknowledged from the beginning by going behind Calvin's back to publish it in Geneva.

Knox believed The First Blast to be an exercise of his Divinely-inspired gift of prophecy; in fact, it antagonized royal power and divided the Christian community, casting doubt on either God's foreknowledge or Knox's. Knox inevitably stood by the tract until his death; he had to, in order to retain authority for anything else he prophesied. Unlike his close friend and fellow Protestant minister Christopher Goodman, who retracted his outspokenly misogynistic politics under heavy Elizabethan pressure in 1571, Knox could not afford to recant because he had a prophetic vocation to protect. ${ }^{3} \mathrm{~A}$ prophet by definition cannot be wrong while exercising his vocation. One standard Biblical test for a false prophet is that events fail to bear out the prophet's message: "When a prophet speaketh in the Name of the Lorde, if the thing followe not nor come to passe, that is the thing which the Lorde hath not spoken, but the prophet hath spoken it presumptuously: thou shalt not therefore be afraid of him." 4 Knox was able to maintain faith in his own prophetic vocation, despite its adverse outcome, only because his chosen Old Testament prophetic models freed him from any direct responsibility for the practical consequences of his words.

That Knox believed himself to be functioning as a prophet during The First Blast is obvious almost from its beginning. He opens with a lament that no "pregnant wittes" or "godlie and zealous preachers" remain in England to denounce "how abominable before God, is the Empire or Rule of a wicked woman, yea, of a traiteiresse and bastard" (4:365). As his argument unfolds, however, clearly wits and preachers are not the roles at issue. It is the "watchemen" who are negligent-an allusion, together with the titular trumpet, to Ezek. 33.2-9, a passage Knox partially explicates later in his introduction, in which the word of the Lord instructs the prophet Ezekiel to be a watchman for Israel and to blow the trumpet of warning 
when he sees danger. "Watchman" is God's word for Ezekiel's prophetic role, and Knox's adoption of it here- - to refer to himself and the rest of the spiritual leaders who have long been silent about the abomination of woman's rule — signifies that he is a prophet like Ezekiel and that The First Blast, whatever other genre it may exemplify, is fundamentally a prophetic oracle. When Knox subsequently rummages through spiritual history for exemplars of the role he is claiming, he cites a slew of prophets first_-"the auncient Prophetes," "the Prophetes of God," "Jeremie," "Ezechiel," "the same Prophetes," "Daniel, and the rest of the Prophetes," "Ezechiel," and "the auncient Prophetes of God" (4:365-67) — before mentioning Christ and Paul, whom he combines with Old Testament prophets under the rubric of God's messengers $(4: 367)$. Having given the Christian era its obligatory nod, Knox quickly returns to prophetic exemplars which almost exclusively inform the ethos he constructs for himself throughout the rest of the introduction: Heliseus [Elisha], the pre-crucifixion Christ as he prophetically denounces Herod, and the passage in Ezekiel from which Knox derives the images of watchman and trumpet. By the time Knox finds his way to his thesis - "to promote a Woman to beare rule, superioritie, dominion, or empire above any Realme, Nation, or Citie, is repugnant to Nature, contumelie to God, a thing most contrarious to his reveled will and approved ordinance; and finallie, it is the subversion of good Order, of all equitie and justice" (4:372) — that thesis bears the weight of a direct prophetic word from the Lord. Knox wrote his introduction to convince its readers of no other thing.

If Knox's work is an oracle in the tradition of Old Testament prophecy, then its readers could expect some direct correlation between its message and events in history. ${ }^{5}$ An Old Testament prophet's mission fundamentally involved the processes of time. Generally following a catastrophic past, a prophecy addressed a present urgent with the responsibility to repent, while in the future loomed sure, and sometimes named, events of judgment and hope. A prophet thus had responsibility to past, present, and future: to interpret the past aright, to prescribe a correct present response to the past, and to predict the future reliably enough that present repentance would be motivated by an assured future judgment and hope. While important, a prophet's pronouncement concerning the future is therefore dependent upon and even secondary to the prophet's interpretation of past and present context.

Knox's method of understanding events and situations of the immediate past, present, and future was to match them up literally, element by element, with Biblical (chiefly Old Testament) events and situations which seemed to him similar. ${ }^{6}$ Again Knox's introduction illustrates the process: 
86 CHAD SCHROCK

We se our countrie set furthe for a pray to foreine nations, we heare the blood of our brethren, the membres of Christ Jesus most cruellie to be shed, and the monstruous empire of a cruell women (the secrete counsel of God excepted) we knowe to be the onlie occasion of all these miseries.... For Israel did universalie decline from God by embracing idolatrie under Ieroboam. In which they did continue even unto the destruction of their common-welthe. (4:365-66)

Knox continues by recounting the spiritual decline of Israel and Judah, which had been duly admonished by glowering and resolute prophets even after they had ceased to be functional nations because of their peoples' sins. Knox, as prophet, witnesses his contemporary situation: England is, he fears, about to be subject to Spain; Protestants are dying; a woman is ruling. He then looks to the Old Testament for a matching narrative pattern and finds it in the declining nations of Israel and Judah. Israel and Judah were losing spiritual autonomy to idols, and political autonomy to the nations that would eventually abolish their independence. Knox needs an element in that narrative pattern of Israelite history to correspond with his contemporary symptom of a woman ruler and complete the correlation between past and present; he finds it in Israelite political self-destruction. Just as Israel destroyed their own commonwealth, England is destroying its political state by putting a woman on the throne. Here Knox's prophecy is oriented, not toward the future, but toward proper interpretation of the present by analyzing it in light of Old Testament narrative patterns with the Biblical, and therefore Divine, seal of approval. 7

The specific narrative pattern with which Knox aligns Christian governments or commonwealths is the primary narrative pattern in the Old Testament: the rise and fall of the loosely theocratic kingdom of Israel. ${ }^{8}$ According to the Biblical story, Israel becomes a full-fledged nation by means of the Deuteronomic covenant in which God and the Israelite people swear to each other an official allegiance. Knox appropriates this covenantal language as early as the 1554 "A Godly Letter to the Faithful in London, Newcastle and Berwick" to describe England's conversion to Protestantism during the reign of Edward vi. ${ }^{9}$ For Knox, Protestant England enjoyed the same relationship to God that Biblical Israel did, and with it the same covenantal responsibilities toward God and toward itself as a political entity. Conversion to Protestantism engaged the mechanism of covenant because, as Jane Dawson explains, "the essential sign of the existence of a covenant relationship was the public acceptance of true religion by the whole of a political community," similar to the Israelite acceptance of the Mosaic Covenant. ${ }^{10}$ If Catholic Spain had acquired a ruling queen, Knox would have felt no need to prophesy; a Spanish queen would still have morally repulsed him, but because Spain, by dint of its Catholicity, was 
in league with the devil, it had very little to lose by further perverting the natural order of God. England, on the other hand, had everything to lose. As a covenanted nation with guaranteed Divine attention, its "royall seate, the throne of justice... oght to be the throne of God" (4:410). Its people "knowe that there is a libertie and fredome, the whiche their predecessors have inioyed; yet are they compelled to bowe their neckes under the yoke of Satan" (4:395). In order to fall, one must have reached a height; England at least had been climbing. From this covenantal perspective, the accession of Mary was a complete debacle; worse, it was accompanied by "insolent joy, the bonefiers, and banketing, which were in London, and els where in England" (4:393). The people were embracing exactly that event calculated "to be the overthrowe of true religion, and the assured destruction of England, and of the auncient liberties therof" (4:394). W. Stanford Reid writes, "By repudiating what Edward had done in bringing about religious change, Mary effectively destroyed the nation's covenant relation with God." ${ }^{11}$ The nation had rejected God's theocracy by embracing a Catholic as ruler.

What exercised Knox most fundamentally in The First Blast, then, was not England's queen but instead its idolatrous covenant-breaking Catholicism, of which the queen served as a convenient symbol. That she was Queen and not King was symptom and not cause of the national sin, for if England would have been worshipping correctly, they would not have embraced Marian rule in the first place. Thus the common impression of The First Blast as Knox's deeply personal misogynistic rant is not justified by the tract's arguments, nor is it justified by external historical evidence, which shows rather that Knox carried on warm, intimate, spiritual relationships of some mutuality and equality with women he considered devout. Both of Knox's marriages, for instance, seem to have been happy ones, and he corresponded with a number of other female parishioners and friends. ${ }^{12}$ Duncan Shaw and Patrick Collinson cite Knox's expressed goodwill toward other female monarchs and his pastoral warmth toward women, respectively, as reasons why The First Blast was aimed at Mary Tudor and at her alone. ${ }^{13}$ While Knox's arguments do refuse secular authority to women in general, Knox's willingness to recognize exceptions to those arguments when considering an actual queen who might further God's covenant_Elizabeth, or Mary, Queen of Scots—permits some separation between an abstract principle, derived from Old Testament law and narrative, and specific contemporaries of Knox whom that principle was to govern. His rhetorical misogyny is therefore not directly equivalent to his personal feelings. ${ }^{14}$

The great irony of Knox's self-depiction as prophet in The First Blast, a tract perceived since its inscription as a quintessentially masculine all-out assault on 
the dignity of women, is that while Knox denies women the right to be heads of state, he admits much more readily by means of historical analogy that God might permit a woman to be a spiritual leader of covenant people, even a prophetess. In his approving description of Deborah as judge, he says:

Debora did usurpe no such power nor authoritie as our Quenes do this day claime; but that she was indued with the spirit of wisdome, of knowledge, and of the true feare of God: and by the same she judged the factes of the rest of the people. She rebuked their defection and idolatry, yea, and also did redresse to her power the injuries that were done by man to man. But all this, I say, she did by the spirituall sworde, that is, by the Worde of God, and not by any temporall regiment or authoritie whiche she did usurpe over Israel. (4:407-08)

Deborah as a woman was not fit for judicial power. She was not permitted to be creative-"she spoileth her self of all power to commande, attributing that authoritie to God" (4:407) — but instead she was imbued, passively, with characteristics appropriate to spiritual leadership. Through her naturally inferior personality the spirit of God was able to operate directly, because she was used to resigning leadership to someone more qualified. Susan Felch writes, "Deborah's actions, flowing as they did from 'the spirit of prophecie which rested upon her,' were not an exercise in authority, but in obedience." 15 This obedience to an external spirit, this willingness to be used, is what Knox commends in her. According to Robert Healey, Knox as prophetic reader of the times was perfectly willing to audition both Elizabeth and Mary, Queen of Scots for the role of Deborah, ${ }^{16}$ but Deborah's womanliness made her particularly good at being a prophetess, not a queen. As a submissive and therefore direct instrument of the spirit of God whose duties were to rebuke defection and idolatry, she resembles Knox's own prophetic persona. At least Knox had an opinion of women high enough to permit them the exceptional role in which he himself took so much pride, ${ }^{17}$ an oblique reference to a kind of spiritual equality which he and women could share. In his view, a woman could have helped to lead England or Scotland, like Israel, spiritually.

In fact, when deducing prophetic truth from Old Testament patterns allows Knox to claim "that particular examples do establishe no common lawe" (4:402) - here in the context of the daughters of Zalphead but alluding to the Biblical prophetesses Huldah and Deborah as well_-it also allows him to claim the reverse: that common law does not necessarily exclude particular exceptions such as the occasional prophetess. Knox reasons that God establishes laws men cannot challenge, and God alone has the freedom to make exceptions to those laws: "God being free, may, for suche causes as be approved by his inscrutable wisdome, dispense with 
the rigor of his lawe, and may use his creatures at his pleasure. But the same power is not permitted to man" (4:404). These laws are the Divinely-sanctioned patterns of history. ${ }^{18}$ Commandments and "mandatory precedents" are what readers ought to get from the Bible. ${ }^{19}$ Once Knox has established to his own satisfaction through Scriptural, classical, and patristic proofs that the regiment of women runs counter to the natural law God has ordained, he can evaluate a particularly successful female monarch as a possible exception. If she successfully promotes the Protestant religion (the only success in which Knox is interested), God has raised her up in his inscrutable wisdom as an exception to his law. If she persecutes the Protestant religion, she must be an abomination, as one would predict a female monarch to be. In this way, Knox feels free to transcend his initial merely pragmatic proofs which establish the general law_- "Such be al women...their sight in civile regiment, is but blindness; their strength, weaknes; their counsel, foolishness; and judgment, phrensie" (4:373-74) — and compliment the women whom he believes deserve it: Deborah, Huldah, and eventually Elizabeth. His condemnation being so general, he can be gracious to any particular woman, as his warm ministerial correspondence with women demonstrates, and can profess bewilderment when Elizabeth takes personally his general condemnation of her sex. Throughout The First Blast, evidence that mitigates or qualifies his argument is dismissed, by Knox, as the work of an inscrutable God taking exception to Divinely-ordained general rules; ${ }^{20}$ evidence that proves his argument, however, he trumpets as its pragmatic justification. The law is the truth. It must be justified in history; there is no alternative for Knox. At the same time, Knox's belief that God transcends human comprehension permits him to sweep all counter-evidence under the freedom of God's activity. For this reason, Knox veers constantly between lauding the value of practical evidence and dismissing it.

As a prophet, Knox believed himself adept in reading the times: the past leading up to the present. He interpreted history exactly as he interpreted a book like the Bible, identifying simple narrative patterns such as the success of a faithful covenanted people and the demise of a people unfaithful to their covenant. He called this historical interpretation part of his prophetic calling. ${ }^{21} \mathrm{His}$ first sermon, in 1547, identified the Biblical Antichrist with the office of the Pope, and much later in life his magisterial work was a History of the Reformation in Scotland which interpreted that history by consistently attempting insight into God's role and intention. ${ }^{22}$ Being a Protestant, Knox did not try to protect the Bible from the people-according to Richard Greaves, in his sermons he "appealed only to the Word of God revealed in Scripture, where it could potentially be understood by any man"23_ but while the 
interpreted word of God was available to anyone, Knox did not believe that most were arriving at his accurate prophetic interpretation unaided. People needed him. His lament in The First Blast, that the English were following Mary joyously to their doom, documents this impression: "What man was there of so base judgement (supposing that he had any light of God) who did not see the erecting of that monstre [that is, Mary], to be the overthrowe of true religion?" (4:394) Evidently, all the men were of so base a judgment; no one shared Knox's clear insight into the present circumstance.

Nor, apparently, could they arrive unaided at an equivalent knowledge of the future. Eventually, in a reflective introduction to his only extant sermon, in 1565, Knox explains his sense of his own superiority:

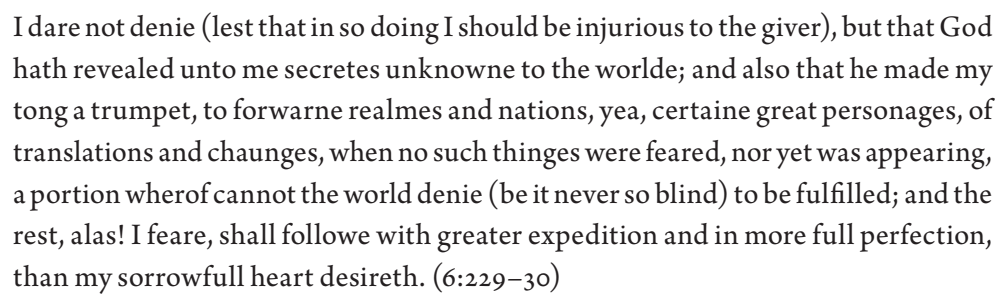

The world is blind. God has given Knox secrets the world does not know, and on the basis of those interpreted secrets, Knox feels justified in forecasting the future even when no obvious signs support his prediction. He is predicting on the basis of Biblical narrative patterns; those who cannot align those patterns with Divine insight concerning current events cannot see where those events are inevitably leading. ${ }^{24} \mathrm{He}$ is also, incidentally, claiming that previous events "wherof cannot the world denie" have vindicated some of his prophecies, although he does not identify which.

On the basis of his God-aided analysis of England's recent past, what Knox does predict in The First Blast for Queen Mary of England, and England itself if it pursues its current covenant-breaking course, is a generalized experience of the wrath of God. The Biblical prophets and apostles persistently proclaimed that "grevous condemnation and Goddes hevie vengeance shuld folowe the proude contempt of graces offred" (4:367), so for Marian England also "the day of vengeance, whiche shall apprehend that horrible monstre Jesabal of England, and such as maintein her monstruous crueltie, is alredie apointed in the counsel of the Eternall" (4:420). This Knox can guarantee on the basis of Biblical models. He thinks that Mary's time is short, and he suspects also that God may be inspiring assassins to "execute his judgementes" (4:420). But that is as far as he can go. His predictions throughout The First Blast are curiously general, often couched in cause-and-effect terminology. 
"Where women reigne or be in authoritie, that there must nedes vanitie be preferred to vertue, ambition and pride to temperancie and modestie; and finallie, that avarice, the mother of all mischefe, must nedes devour equitie and justice" (4:375) and "Horrible is the vengeance which is prepared for the one and for the other, for the promoters [of women], and for the persones promoted, except they spedelie repent" (4:378) do not predict inescapable events but identify inescapable causal chains if a posited initial action is taken and sustained. As Richard Kyle has argued, while John Knox "believed that God had endowed him with the ability for both types of prophecies: the word of admonition and the knowledge of future events... on the whole, admonition clearly took precedence over prediction." ${ }^{25}$ Knox does not want to seal off the future but to give his readers an opportunity to repent and change it. Change the cause, and the amorphous but looming judgment will be averted.

Because his predictions are merely general, Knox does not have to recant The First Blast on the basis of failed prophecy. Mary the Catholic queen does not refute his prophetic interpretation of her by presiding over a long, happy, and prosperous reign. Perhaps that and that alone could have scuttled his claim to prophecy. While Elizabeth did achieve success as queen, Knox had built an exception clause right into his argument, beginning its third paragraph and qualifying all that follows: "I except such [women] as God, by singular priviledge, and for certain causes, knowen onlie to himselfe, hath exempted from the common ranke of women" (4:374). In a 1559 letter to Elizabeth, he claimed that God had made her a merciful exception to the usual strictures on women: "Nothing in my booke contained, is, or can be prejudicial to your Grace's just regiment, provided that ye be not found ungrateful unto God [and] to the dispensation of his mercie, which onlie maketh that truthfull to your Grace, which nature and law denieth to all weomen" (6:49). If she were properly apprised of her unique privilege as a God-ordained governess, and obeyed God accordingly, The First Blast no longer applied to her.

Although no direct failure of prediction exposed Knox as false prophet in the wake of The First Blast, his tract surely had an effect opposite to what he had intended. Rather than rallying the English to topple Catholicism and erect radical Protestantism on its ruins-necessarily with the help of an unnamed male Protestant monarch — his blast infuriated and alienated the eventual heir to the English throne, Elizabeth, and helped to ensure the (to him) entirely unsatisfactory via media of Elizabethan Protestantism. His own description of his role as prophet, however, left room for and even predicted the pragmatic failure of his message.

Knox had to find his own role models in one of two specific prophetic periods in Israel's covenant history: at its beginning and during its decline. The prophet 
92 CHAD SCHROCK

Moses inaugurated the Deuteronomic covenant; his political activism, admonition, law-giving, and supernatural leadership helped to form the incipient nation despite the recalcitrance of its members who had stumbled and grumbled after Moses for 40 years, wishing they were back under the ungodly yoke of the Egyptian. Moses belabored the Israelites with guilt-inducing diatribes which, after 40 years, succeeded; Israel stormed the Promised Land and swore a national covenant to God. The natural prophet for Knox to associate himself with on the covenant history schema was Moses. England had just become a covenanted nation, according to Knox's interpretation of history. Its best years were ahead. The Marian reign could be at worst an interlude before the covenanted nation rallied. The day of vengeance Knox does prophesy he confines to Mary and the Papists; England itself would surely rise again. His search for a Deborah-figure within a newly covenanted nation like England or Scotland would mean that they, like Israel, were on the increase despite a grumbling and resistant multitude, for Deborah had ruled in Israel soon after Moses. Finally, in his dealings with Scotland a few years later, Knox fondly thought of himself as "the Joshua of the Scots," the man who brought the chosen people into the Promised Land after Moses was dead, the man who successfully established the Israelite covenant as a political and religious institution. ${ }^{26}$

But in The First Blast the prophetic identities Knox persistently appropriates for his own are unexpectedly those of the later prophets: of Elisha, after whom Israel had no good king; of Jeremiah, prophet when Babylon conquered Israel's sister kingdom Judah; and worst of all, of Daniel and Ezekiel, prophets of exile, after whom the Jews did not achieve independence for 400 years. ${ }^{27}$ During the ministry of these prophets, the covenant of Israel is old and decrepit, its people lax and uninterested. The prophets' voices grow progressively more panicked as politeness, then raised voices, then raw screams fail to effect the desired repentance. They are trying to turn back the inevitable, achieving fitful regatherings of devotion at best. Even Knox's Biblical models in The First Blast for Mary Tudor imply the ultimate futility of prophetic resistance. Mary is Jezebel, ground gorily underneath Jehu's chariot wheels but succeeded on the throne by that violent idolater; she is Athaliah, assassinated by a priest ( $4: 416)$ but succeeded by a young boy who grows up to be a tyrant. Knox simply does not have a Biblical example of a prophetic call to repentance inducing permanent political and spiritual recovery. While his words are aggressive, bold, and hopeful, the Biblical patterns he cites for his own behaviour sabotage his optimism. Within the Biblical rhetoric he used, whether he knew it or not, was the code of his disaster.

Despite the near-unanimous disapproval of his peers, Knox is, then, extraordinarily aware of himself in context. He is a prophet to a nation recently fallen 
from obedience and, as such, he acknowledges the probability that his message will fail. Early in his introduction he directly refutes the objection to The First Blast later raised implicitly by most of his Reformer friends and explicitly by this essay: how can you call The First Blast the right thing to do when it results in everything you would not wish for? Knox is not stupid.

The naturall man, ennemy to God shall fynd, I knowe, many causes why no suche doctrine oght to be published in those our dangerous dayes. First, for that it may seme to tend to sedition. Secondarilie, it shall be dangerous, not onlie to the writer or publisher, but also to all such as shall reade the writinges, or favor this truth spoken: And last, It shall not amend the chief offenders, partlie because it shall never come to their eares, and partlie because they will not be admonished in such cases. (4:367)

If a paper is seditious and thus quasi-immoral; if a paper endangers writer, publisher, and reader; if a paper will not cause the change it is written to demand, any natural or reasonable — even ethically responsible — mind would not publish the paper. But Knox as a prophet does not have to live in a natural, reasonable, or pragmatic world: "I answer, Yf any of these be a sufficient reason, that a truth knowen shall be conceled, then were the auncient Prophetes of God very fooles, who did not better provide for their owne quietnes, then to hasard their lives for rebuking of vices, and for the opening of such crimes as were not knowen to the world" (4:367). Truth, named, is its own justification. It permits the possibility of repentance (4:368), whether or not that opportunity is taken. It achieves its true reward for the prophet only in that "kingdome [which] Christ hath promised to such as persevere in profession of his name to the end" (4:368), as opposed to these present inconstant kingdoms, the rewards of the natural, the reasonable, the pragmatic, the merely ethical. In the way Knox describes his prophetic responsibility, absolutely no consequence could have either dissuaded him from writing what he believed to be true or caused him to reflect afterward that that writing had been a mistake-not even the accession and hostility of a Protestant Elizabeth nor the aversion of his fellow Reformers. ${ }^{28}$ Such is the luxury, and the burden, of a prophet.

His quintessential reading of ambiguous pragmatic consequence in The First Blast is his conclusion, in which he retells the Biblical story of the Israelites losing twice to the tribe of Benjamin before they managed to defeat it and punish its blatant wickedness. It is possible for good actions to seem to fail.

The secret cause of this, I say, is known to God alone. But by his evident scriptures we may assuredly gather, that by such means doth his wisdome sometimes beat downe the pride of the flesh (for the Israelites at the firste trusted in their multitude, power and strength,) and sometimes by such overthrowes, he will punishe the offenses of 
94 CHAD SCHROCK

his owne children, and bring them to the unfeined knowledge of the same, before

he will geve them victorie against the manifest contemners. (4:418)

Victory, Knox believes, is inevitable eventually, if not immediately. For various reasons-punishments of sins chiefly cited here-God may give the evil side provisional victory. Those who know the truth are not to be misled by circumstances which seem to deny the immediate efficacy of the truth. The truth is ultimately, but only ultimately, efficacious and vindicated. ${ }^{29}$ Knox goes on to apply this insight to the Marian reign: "In the beginning of this their bloodie reigne, the harvest of their iniquitie was not comen to full maturitie and ripenes: No! it was so grene,... so covered, and so hid with hypocrisie, that some men (even the servantes of God) thoght it not impossible but that wolves might be changed in to lambes, and also that the vipere might remove her natural venom" (4:419). In viewing the success of Mary as a Catholic woman ruler, against the forecast of all the laws they knew, men began to wonder if those natural laws had now been suspended. The world was now so changed that wolves became lambs, vipers poisonless, and women effective rulers. According to Knox, God was letting Mary's evil have its day, its full fruition, before He brought the judgment which Knox was writing his First Blast to proclaim. Mary's initial success signified nothing about God's approval of her position. People had to start with the correct Biblical narrative pattern (prophetically supplied) and work forward, not the contemporary pattern and work backward.

Knox wrote The First Blast as one prophet against the world, against circumstantial evidence, against the pragmatic considerations of political expediency. $\mathrm{He}$ could do no other because he believed he had been given a truth from God which would eventually, perhaps even beyond the scope of his experience, be justified. Prophecy was not a creative act on the part of the prophet. God gave the message, and Knox delivered it, come hell, high water, or Elizabeth. On the one hand, Knox could dissociate himself from The First Blast far more than most authors would be able to. He wrote it, but as a prophetic oracle it was not his at all; he could even personally hope that Elizabeth or Mary, Queen of Scots would be an exception to the rule he had prophesied. On the other hand, prophetic authority derived from God, exempt as Knox describes it from all pragmatic considerations, looks imposing indeed.

\section{Notes}

1. Richard L. Greaves, Theology and Revolution in the Scottish Reformation: Studies in the Thought of John Knox (Grand Rapids, MI: Christian University Press, 1980), pp. $165-66$. 
2. John Knox, The Works of John Knox, ed. David Laing, 6 vols. (Edinburgh: J. Thin, 1854), vol. 4, p. 357. Quotations from Knox's Works are hereafter cited in the text according to volume number and page number.

3. Knox did reveal some regret about the pugnacious attitude he took within The First Blast, but did not retract its content, as demonstrated by his letter to John Foxe dated 18 May 1558 :

My rude vehemencie and inconsidered affirmations, which may appear rather to procead from coler then of zeal and reason, I do not excuse; but to have used anye other tytle mor plausible, therby to have allured the world by any art, as I never purposed, so do I not yet purpose: to me it is yneugh to say that black is not whit, and man's tyrannye and foolishnes is not Goddes perfite ordinance; which thinge I do, not so much to correct common welthes as to delyver my own conscience, and to instruct the consciences of som semple, who yit I fear be ignorant in that matter. (5:5)

Rhetorically this sentence reveals an unrepentant author, temporarily admitting the justice of his detractors before claiming virtues in The First Blast that a more careful presentation (obeying the cautions of his detractors) would have precluded.

4. Deut. 18.22 ( 1587 Geneva Bible).

5. See Abraham Heschel, The Prophets (New York: Harper \& Row, 1962), pp. 3-26, for an authoritative portrait of the prophetic vocation in the Old Testament; he also defines prophecy as "exegesis of existence from a divine perspective" (xviii).

6. According to Katharine R. Firth, The Apocalyptic Tradition in Reformation Britain 1530-1645 (Oxford: Oxford University Press, 1979), pp. 125-26, the Bible was to John Knox "a handbook for the judgement of God upon nations and powers in the world. When circumstances matched, then similar conclusions followed. By using the examples of Scripture he called down the same judgements upon his contemporaries that he found in Scripture.” Peter Auksi, “'God Shall Always Raise Up Some': John Knox, the Reformer as Prophet," Florilegium 17 (2000), pp. 282-83, discusses Knox's similar strategy when writing the History of the Reformation in Scotland.

7. See Richard Kyle, "John Knox and Apocalyptic Thought," Sixteenth Century Journal 15 (1984), p. 458, for further details: "The exegetical method of drawing analogies between biblical and contemporary events for the purpose of promoting one's policies was called 'prophesying' by the Marian exiles and the Puritans."

8. The other Biblical political narrative Knox mentions is the Fall of man and woman. He reads this as a demonstration of woman's mis-government over man. Eve caused Adam to fall because she was intrinsically inferior to him, "imprudent and soft" (4:387), which meant that she had no way to exercise proper authority over the man. When he yielded to her in any way, the outcome was inevitably failure. "Thou couldest not bear rule" (4:387), Knox quotes Chrysostom as saying, because the one time man genuinely submitted to woman, the disaster of original sin was its result. 
9. Unlike other reformers such as Calvin, Knox's thought began with the covenant as a political institution and only later applied covenantal principles to the relationship between God and the individual, ratified in baptism. See W. Stanford Reid, "John Knox's Theology of Political Government," Sixteenth Century Journal 19 (1988), p. 531, and Greaves, pp. 118-19.

10. Jane E. A. Dawson, "Trumpeting Resistance: Christopher Goodman and John Knox," in John Knox and the British Reformations, ed. Roger A. Mason (Brookfield, VT: Ashgate, 1998), p. 141.

11. W. Stanford Reid, Trumpeter of God: A Biography of John Knox (New York: Scribner's, 1974), p. 532.

12. Susan Felch, "The Rhetoric of Biblical Authority: John Knox and the Question of Women," Sixteenth Century Journal 26 (1995), p. 807, identifies a number of key scholars who argue for Knox's misogyny. Felch's article as a whole discusses Knox’s correspondence with women and concludes that Knox's exercise of pastoral authority was not misogynistic but had the best interests of women at heart, those best interests being of course defined by sixteenth-century Protestant interpretations of the Bible, including and especially Knox's own.

13. Duncan Shaw, John Knox and Mary, Queen of Scots (Edinburgh: Saint Andrew Press, 1975), p. 17; Patrick Collinson, "Knox, the Church, and the Women of England," in John Knox and the British Reformations, ed. Roger A. Mason (Brookfield, vT: Ashgate, 1998), p. 78.

14. On the basis of Knox's pastoral correspondence with women, Jasper Ridley, John Knox (New York: Oxford University Press, 1968), p. 267, concludes that Knox in The First Blast is pandering "to popular prejudices which he personally did not really share." In this reading, Knox's personal feelings directly oppose his rhetorical stance.

15. Felch, p. 818 .

16. Robert M. Healey, "Waiting for Deborah: John Knox and Four Ruling Queens," Sixteenth Century Journal 25 (1994), pp. 379-83.

17. Ironically, as A. N. McLaren, "Delineating the Elizabethan Body Politic: Knox, Aylmer and the Definition of Counsel 1558-88," History of Political Thought 17 (1996), pp. $237-38$, points out, Aylmer's refutation of Knox admits that Knox's Biblical evidence excludes women from spiritual leadership. Aylmer instead focuses his argument on tentatively reclaiming the civil sphere for women, an exact reversal of Knox's concession.

18. Jane Dawson, “The Two John Knoxes: England, Scotland and the 1558 Tracts," Journal of Ecclesiastical History 42 (1991), p. 564, writes:

The identification of absolute laws was a technique which he had borrowed from his Old Testament exegesis.... By tying his rules to the absolute authority of God Himself, Knox sought to place them beyond doubt or contradiction. Any variations permitted by local laws, habit or custom could then be ignored. The rules were declared to be absolutely binding and applicable to each and every circum- 
stance, place and person. This elevation of a rule to the status of an immutable law removed the possibility of compromise. Knox could then present the case as a matter of stark alternatives, obedience or disobedience to a great principle of law.... Having fixed this law, Knox could designate any deviation as monstrous and insist that it be removed.

This is true as far as it goes; Knox, however, does not ignore these variations but feels free to mention them and to attribute their existence to God justly exercising His sovereignty for His purposes. If we were to make such exceptions, then the monstrosity would begin.

19. Dawson, "Trumpeting Resistance," p. 135.

20. Constance Jordan, "Woman's Rule in Sixteenth-Century British Political Thought," Renaissance Quarterly 40 (1987), p. 436.

21. Jordan, pp. 426, 434, distinguishes Knox's conservative exegetical position from Aylmer's more liberal one in his refutation of Knox by claiming that Knox derived his arguments from authority, while Aylmer derived his from the experience of history. Aylmer's experiential and historical arguments demonstrated the historical contingency of Scripture and undermined its direct authority; Jordan believes that Aylmer won at least that part of the argument. While our perspective may show that Knox drew evidence from authority as separate from or even opposed to the events of history, Knox would not have conceded. He genuinely thought that history supported his authorities. His appeal to authority is an appeal to a prophetic view of history, which truth ought to be obvious to all readers once the insight is given.

22. For a detailed narrative of Knox's evolving understanding of his prophetic calling and "special powers," including prescience, see Firth, pp. 114-18, 125-30. Firth emphasizes Knox's strong belief in his own (derived) prescient powers, but as I argue, following Kyle, p. 456, prescience is not the primary prophetic function Knox is exercising during The First Blast.

23. Greaves, p. 20.

24. In the middle of the prophetic introduction to The First Blast, Knox admits that he does not have access to the entire mind and intention of God- "the secrete counsel of God excepted" (4:365) might contradict his reading of present events-but this does not disprove that Knox knows more of the counsel of God than most.

25. Kyle, p. 456.

26. Shaw, p. 5 .

27. Dawson, "Knox, John (c.1514-1572)," Oxford Dictionary of National Biography (Oxford: Oxford University Press, 2004), http://www.oxforddnb.com/view/article/15781 (accessed 6 July 2007), links Knox's exilic prophetic persona to his experience as a Genevan exile, but the situations are not exactly equivalent, and that may in fact be what enables Knox to place his own role in such ambiguity. Although he was participating in the birth of Protestant Britain, his personal fate as Genevan exile is more 
98 CHAD SCHROCK

like something that would happen to a prophet much later in Israel's history; so he can claim equivalence with whichever epoch suits his need at the moment.

28. The recently published letters in Jane Dawson and Lionel K. Glassey, "Some Unpublished Letters from John Knox to Christopher Goodman,” Scottish Historical Review 84 (2005), illustrate the precedence in Knox's later life of what the editors, on p. 179, call "apocalyptic gloom." Even in 1569, however, the increasingly defensive and disappointed Knox is no complete pessimist: acknowledging to Goodman that "it has not so prosperously succeeded with your freende in this countrey... as we both wold have wissed," he can still "praise god it is no worse" and assure Goodman that God will eventually reveal the crimes of Mary, queen of Scots, and her associates despite "misty \& troubled dark wedther [which] hydes [them] for a seasson" (198). Apocalypse, after all, though unpleasant and disheartening to undergo, is exactly what a late Old Testament Biblical prophet would expect.

29. Kyle, pp. 462-68, argues that Knox did believe himself to be living in some kind of "last days," which the coming of Christ inaugurated, but that his apocalyptic descriptions of the Antichrist's activity in history stretched over the entire Christian era and did not imply that the end of history was imminent. 